Fakultas Hukum, Universitas Lampung, Bandar Lampung, Lampung, Indonesia. http://jurnal.fh.unila.ac.id/index.php/corruptio

Volume 01 Issue 2, July-December 2020. PP: 105-116

P-ISSN: $2723-2573$

E-ISSN: 2745-9276

\title{
Kebijakan Formulasi Ketentuan Pengembalian Aset Hasil Tindak Pidana Korupsi
}

\section{Policy on the Formulation of Provisions for Returning the Proceeds of Corruption Crimes}

\author{
Kusnadi \\ pemburukoruptor96@gmail.com
}

Jaksa

Submitted: Jul 27, 2020; Reviewed: August 19, 2020; Accepted: Sept 11, 2020

\begin{tabular}{|c|c|}
\hline Info Artikel & Abstrak \\
\hline $\begin{array}{l}\text { Kata Kunci: Formulasi; Pengembalian Aset; } \\
\text { Korupsi. } \\
\text { Keywords: Formulations; Asset Returns; } \\
\text { Corruption. }\end{array}$ & $\begin{array}{l}\text { Aparat penegak hukum dalam } \\
\text { penyelesaian perkara tindak pidana } \\
\text { korupsi, tidak hanya mengedepankan } \\
\text { penghukuman fisik semata, tetapi juga } \\
\text { mengutamakan pengembalian kerugian } \\
\text { keuangan negara melalui pengembalian } \\
\text { aset, oleh karena itu dibutuhkan adanya } \\
\text { sistem yang memungkin dilakukannya } \\
\text { penyitaan dan perampasan aset hasil } \\
\text { tindak pidana korupsi secara efektif dan } \\
\text { efisien. Kebijakan Formulasi Ketentuan } \\
\text { Pengembalian Aset Hasil Tindak Pidana } \\
\text { Korupsi di Indonesia saat ini tersebar di } \\
\text { beberapa perundang-undangan } \\
\text { diantaranya KUHP, KUHAP, UU } \\
\text { Pemberantasan Tindak Pidana Korupsi } \\
\text { (UU PTPK), UU Tindak Pidana } \\
\text { Pencucian Uang (UU TPPU) maupun } \\
\text { United Nations Convention against } \\
\text { Corruption (UNCAC) 2003. Formulasi } \\
\text { ketentuan pengembalian aset pada masa } \\
\text { yang akan datang dapat menerapkan } \\
\text { konsep perampasan atas harta hasil }\end{array}$ \\
\hline
\end{tabular}


korupsi tanpa penghukuman pidana sesuai ketentuan Pasal 54 Ayat (1) huruf c UNCAC 2003. Pendekatan penelitian menggunakan pendekatan yuridis normatif dan pendekatan yuridis empiris. Narasumber terdiri dari para Jaksa di lingkungan Kejaksaan Agung RI, serta Dosen Hukum Pidana Fakultas Hukum Unila. Pengumpulan data dilakukan dengan studi pustaka dan studi lapangan. Analisis data dilakukan secara kualitatif dan selanjutnya diambil simpulan. Hasil penelitian menunjukkan bahwa formulasi ketentuan pengembalian aset hasil tindak pidana korupsi saat ini menganut konsep perampasan aset melalui putusan pengadilan yang telah memiliki kekuatan hukum tetap sedangkan Formulasi ketentuan pengembalian aset hasil tindak pidana korupsi pada masa yang akan datang diwujudkan dengan mempertimbangkan kepentingan Negara atau masyarakat selaku korban dari tindak pidana korupsi dengan menerapkan konsep Belanda yaitu pemulihan aset pasca putusan pengadilan, berdasarkan konsep perampasan aset terhadap keuntungan yang diperoleh dari hasil tindak pidana, serta menerapkan konsep perampasan aset secara perdata tanpa didahului sanksi pidana sebagaimana telah dirumuskan dalam Pasal 1 ayat (3) RUU Perampasan Aset Tindak Pidana. Saran dalam penelitian ini hendaknya Pemerintah maupun DPR melakukan harmonisasi ketentuan pengembalian aset yang terdapat dalam UU PTPK serta UU TPPU agar selaras dengan konsep pengembalian aset (Asset Recovery) yang diatur dalam UNCAC 2003, menerapkan konsep pengembalian aset pasca putusan pengadilan dan konsep perampasan aset terhadap keuntungan yang diperoleh dari hasil tindak pidana terhadap perubahan UU PTPK, dan segera mengesahkan RUU Perampasan Aset Tindak Pidana menjadi Undang-Undang guna efektifitas pengembalian aset hasil tindak pidana 
korupsi.

Abstrac
Law enforcement officials in settling cases of corruption do not only prioritize physical punishment, but also prioritize the recovery of state financial losses through the return of assets, therefore a system is needed that allows for the confiscation and seizure of assets resulting from corrupt acts effectively and efficiently. Policy on the Formulation of Provisions for Returning Assets resulting from Corruption in Indonesia is currently scattered in several laws including the Criminal Code, the Criminal Procedure Code, the Corruption Eradication Act (PTPK Law), the Law on Money Laundering (UU TPPU) and the United Nations Convention against Corruption UNCAC) 2003. Formulation of provisions for returning assets in the future can apply the concept of confiscation of assets resulting from corruption without criminal penalties in accordance with Article 54 paragraph (1) letter $c$ of UNCAC 2003. The research approach uses a normative juridical approach and an empirical juridical approach. The speakers consisted of prosecutors in the Indonesian Attorney General's Office, as well as Lecturers in Criminal Law at the Faculty of Law, University Lampung. Data collection was carried out with literature and field studies. Data analysis was performed qualitatively and then conclusions were drawn. The results of the study show that the formulation of the provisions for returning assets as a result of corruption acts currently adheres to the concept of appropriation of assets through a court decision that has permanent legal force while the formulation of the provisions for returning assets as a result of corruption in the future is realized taking into account the interests of the State or the community as victims from criminal acts 
of corruption by applying the Dutch concept of recovery of assets after a court decision, based on the concept of appropriation of assets against profits derived from the results of criminal acts, as well as applying the concept of appropriation of assets in a civil manner without being preceded by criminal sanctions as formulated in Article 1 paragraph (3) of the Draft Bill Confiscation of Criminal Asset. Suggestions in this study should be the Government and the Parliament to harmonize the provisions of asset recovery contained in the PTPK Law and the TPPU Law to be in line with the concept of asset recovery (Asset Recovery) regulated in UNCAC 2003, to apply the concept of asset return after a court decision and the concept of appropriation of assets against profits. Obtained from the results of a criminal offense against amendments to the PTPK Law, and immediately ratified the Criminal Asset Seizure Draft Bill into Laws for effective return of assets resulting from a criminal act of corruption.

\section{A. Pendahuluan}

Indonesia merupakan negara dengan jumlah kasus korupsi yang cukup banyak. Tindak pidana korupsi di Indonesia sudah mengalami perkembangan yang sangat luas dan telah masuk sampai ke dalam seluruh lapisan kehidupan masyarakat. Perkembangannya terus meningkat dari tahun ke tahun, dalam jumlah kasus yang terjadi dan jumlah kerugian keuangan negara serta dari segi kualitas tindak pidana korupsi yang dilakukan semakin sistematis yang telah memasuki aspek kehidupan masyarakat. ${ }^{1}$ Korupsi tidak hanya dapat merugikan keuangan negara, tetapi lebih dari itu korupsi juga merupakan pelanggaran terhadap hak-hak social dan ekonomi masyarakat secara luas. ${ }^{2}$ Korupsi sebagai tindak pidana yang membuat perhatian serius para pemimpin bangsa Indonesia dari masa ke masa untuk memberantasnya. Sebab korupsi merupakan kejahatan kerah putih (White Collar Crime) atau

\footnotetext{
${ }^{1}$ Megawati, "Kebijakan Formulasi Sanksi Pidana Terhadap Pelaku Tindak Pidana Korupsi.” USU Law Journal. Vol. 2. No. 3. (2014).hlm. 125.

2 Deypend Tommy Sibuea, R.B. Sularto, Dan Budi Wisaksono, "Kebijakan Hukum Pidana Dalam Perampasan Aset Hasil Tindak Pidana Korupsi Di Indonesia.” Diponegoro Law Journal. Vol.5 No. 2. (2016). hlm. 2.
} 
kejahatan berdasi dan modus operandinya dilakukan dengan cara-cara yang canggih. ${ }^{3}$ Korupsi juga menjadi persoalan negara-negara lain di belahan dunia ini. Tindak pidana korupsi menggambarkan kejahatan yang dipandang telah berakibat meruntuhkan sendi kehidupan bermasyarakat, berbangsa dan bernegara. Korupsi sebagai kejahatan, tidak saja merugikan keuangan dan perekonomian negara melainkan juga merugikan individual maupun kelompok masyarakat lainnya. ${ }^{4}$ Untuk mengatasi hal tersebut, maka Indonesia melakukan berbagai upaya untuk pencegahan tindak pidana korupsi.

Indonesia telah meratifikasi konvensi anti korupsi dengan Undang-Undang Nomor 7 Tahun 2006 tentang Pengesahan United Nations Convention Against Corruption (Konvensi Perserikatan Bangsa-Bangsa Anti Korupsi) tahun 2003 guna menjalin kerjasama internasional dalam rangka pemberantasan dan pencegahan tindak pidana korupsi secara lokal dan internasional. ${ }^{5}$ Berdasarkan hal tersebut maka, dalam menanggulangi tindak pidana korupsi ini dimulai dengan sifat yang berupa pencegahan atau preventif maupun yang represif. ${ }^{6}$ Namun pemberantasan korupsi serta penyelamatan aset negara, hendaknya harus dilakukan juga secara komprehensif dan sistematik. ${ }^{7}$ Karena salah satu isu yang paling krusial untuk dipecahkan oleh bangsa dan pemerintah Indonesia adalah masalah korupsi. ${ }^{8}$ Dalam memberikan hukuman pada pelaku tindak pidana korupsi tentunya memiliki tujuan pemidanaan yaitu untuk memberikan efek jera bagi para pelaku tindak pidana. Jika penerapan sanksi pidana dalam pemidanaan merupakan suatu penghukuman agar pelaku tindak pidana tidak lagi mengulangi perbuatannya dimasa yang akan datang. ${ }^{9}$

Penegakan hukum dan pemulihan aset kejahatan merupakan dua sisi mata uang yang tidak dapat dipisahkan dalam pemberantasan tindak pidana khususnya tindak pidana korupsi. ${ }^{10}$ Penegakan hukum dibidang tindak pidana korupsi idealnya adalah menangkap pelaku korupsi tersebut, menuntutnya ke pengadilan kemudian mengembalikan hasil kejahatan dari tindak pidana korupsi kepada negara. ${ }^{11}$ Akan tetapi nalar pemikiran hukum tersebut belum betul-betul diimplementasikan dalam praktik penegakan hukum tindak pidana korupsi di Indonesia. Penegakan hukum tindak pidana korupsi tidak seharusnya hanya terputus pada memidana pelaku saja akan tetapi harus bisa secara konkret mengembalikan aset dari hasil tindak pidana korupsi untuk negara.

Usaha pengembalian aset negara yang telah dicuri koruptor (stolen asset recovery) sangat sulit dilakukan, sebab korupsi di Indonesia tidak saja telah membudaya namun juga telah melembaga. Perilaku menyimpang itu telah mengalami proses institusionalisasi, sehingga hampir-hampir tidak ada lembaga negara yang steril dari perilaku menyimpang tersebut. ${ }^{12}$

\footnotetext{
3 Ade Mahmud, "Problematika Asset Recovery Dalam Pengembalian Kerugian Negara Akibat Tindak Pidana Korupsi." journal Yudisial. Vol. 11. No. 3. (2018).hlm. 350.

${ }^{4}$ I Gusti Ketut Ariawan, "Stolen Asset Recovery Initiative, Suatu Harapan Dalam Pengembalian Aset Negara." Jurnal Kertha Patrika. Vol. 33. No. 1 (2008).

${ }^{5}$ Muhammad Habibi, "Independensi Kewenangan Komisi Pemberantasan Korupsi Pasca Perubahan Undang-Undang Nomor 30 Tahun 2002 tentang Komisi Pemberantasan Korupsi”, journal Cepalo, 4 (1), (2020).

${ }^{6}$ Atep Abdurofiq, "Politik Hukum Ratifikasi Konvensi Pbb Anti Korupsi Di Indonesia." Jurnal Cita Hukum. Vol.4 No. 2. (2016).hlm. 189

${ }^{7}$ Evans Emanuel Sinulingga, "Pengembalian Aset Hasil Tindak Pidana Korupsi Melalui Mekanisme Gugatan Perdata." Jurnal Lex Administratum, Vol. V. No. 4. (2017).hlm.124.

${ }^{8}$ Samuel Mangapul Tampubolon, "Peran Pemerintah Dalam Upaya Pemberantasan Korupsi Kaitannya Dengan UndangUndang No. 32 Tahun 2004.” Jurnal Lex Et Societatis. Vol. II. No. 6. (2014).

${ }^{9}$ Heri Jerman, "Pemulihan Aset Hasil Kejahatan Sebagai Bentuk Perlindungan Hukum Terhadap Korban Kejahatan." DIH Jurnal Ilmu Hukum. Vol. 13 No. 25 (2017).hlm.149.

${ }^{10}$ Aliyth Prakarsa dan Rena Yulia, "Model Pengembalian Aset (Asset Recovery) Sebagai Alternatif Memulihkan Kerugian Negara Dalam Perkara Tindak Pidana Korupsi.” Jurnal Hukum PRIORIS. Vol. 6 No. 1 (2017).hlm.32.

${ }^{11}$ Requisitoire Law Enforcement \& Justice Magazine, Volume 31 Tahun 2013, hlm. 54.

12 I Ketut Rai Setiabudhi \& I Gede Artha, "Vonis Sanksi Pidana Tambahan Oleh Hakim Berupa Pengembalian Kerugian Keuangan Negara Oleh Terpidana Tindak Pidana Korupsi Di Pengadilan Negeri Denpasar." Jurnal Magister Hukum Udayana. Vol. 6. No. 2. (2016).Hlm. 295.
} 
Beberapa pemain tindak pidana korupsi mempunyai jalan yang sulit dijangkau dan cukup luas dalam menyembunyikan ataupun melakukan pencucian uang (money laundering) dari hasil tindak pidana korupsi yang dilakukannya. Pengembalian aset merupakan isu pokok sebab pencurian aset negara pada negara-negara yang sedang berkembang, dilakukan oleh pelaku yang telah berkuasa di negara yang bersangkutan, hal tersebut merupakan masalah yang cukup serius. Pada negara Indonesia, korupsi telah membuat kerugian besar dari keuangan negara. untuk mengembalikan aset-aset yang telah dicuri, salah satu prasyarat yang dibutuhkan adalah kemauan politik negara.

Kemampuan politik dari parlemen terkait dengan seperangkat aturan hukum yang harus disipkan mulai dari pelacakan aset, pembekuan aset, penyitaan aset, perampasan aset, pengelolaan aset, penyerahan aset sampai pada pemanfaatan dan pengawasan aset yang telah diserahkan. ${ }^{13}$ Pengembalian aset-aset negara yang dicuri (Stolen Asset Recovery) sangat penting bagi pembangunan negara-negara berkembangan karena pengembalian aset-aset yang dicuri tidak semata-mata merestorasi aset-aset negara berkembang tetapi juga bertujuan untuk menegakkan supremasi hukum dimana tidak satu orangpun kebal terhadap hukum. ${ }^{14}$

Bahasan diatas menampilkan adanya kebutuhan yang konkrit terhadap suatu sistem yang memungkinkan dilakukannya penyitaan dan perampasan aset hasil tindak pidana korupsi secara efisien dan efektif. Kebijakan Formulasi Ketentuan Pengembalian Aset Hasil Tindak Pidana Korupsi di Indonesia saat ini tersebar di beberapa perundang-undangan diantaranya KUHP, KUHAP, UU No 31 Tahun 1999 juncto UU No 20 Tahun 2001 tentang Pemberantasan Tindak Pidana Korupsi (UU PTPK), UU No. 8 Tahun 2010 tentang Pencegahan dan Pemberantasan Tindak Pidana Pencucian Uang (UU TPPU) maupun United Nations Convention Against Corruption, 2003 (UNCAC 2003). Formulasi ketentuan pengembalian aset pada masa yang akan datang dapat menerapkan konsep perampasan atas harta hasil korupsi tanpa penghukuman pidana sesuai ketentuan Pasal 54 Ayat (1) huruf c UNCAC 2003.

\section{B. Pembahasan}

\section{Kebijakan Formulasi Ketentuan Pengembalian Aset Hasil Tindak Pidana Korupsi di Indonesia}

Pengembalian aset hasil tindak pidana korupsi sebagai kebijakan sosial diwujudkan dalam institusi budaya, institusi hukum, institusi politik, organisasi pengembalian aset hasil tindak pidana korupsi dalam masyarakat yang bertujuan memajukan kesejahteraan umum dengan cara mengoptimalkan penggunaan hak-hak negara dalam mengejar dan mendapatkan kembali aset hasil tindak pidana korupsi berdasarkan prinsip-prinsip solidaritas dan saling mendukung. ${ }^{15}$ Proses pengembalian aset berdasarkan pendekatan hukum pidana merupakan salah satu bentuk pemidanaan, khususnya dalam tindak pidana yang berkaitan dengan keuangan negara atau yang bertujuan memperoleh keuntungan materiil. Menurut Pasal 18 ayat (2) UU PTPK perampasan aset berdasarkan kesalahan terdakwa (conviction based assets for feiture) artinya, perampasan suatu aset hasil tindak pidana korupsi sangat tergantung pada keberhasilan penyidikan dan penuntutan kasus pidana tersebut. ${ }^{16}$

\footnotetext{
${ }^{13}$ Eddy O.S Hiariej, "Pengembalian Aset Kejahatan.” Jurnal Opinio Juris. Vol. 13 (2013).hlm. 34.

${ }_{14}$ Muhamad Rakhmat, "Kewenangan Kejaksaan dalam Pengembalian Aset Hasil Korupsi melalui Instrumen Hukum Perdata." Mimbar: Jurnal Sosial dan Pembangunan. Vol. 31. No. 1. (2015). hlm. 203.

15 Ayu Puspita Sari Situmeang, Dewa Gede Sudika Mangku \& Ni Putu Rai Yuliartini. "Pengembalian Aset Negara Yang Dicuri Sebagai Hasil Tindak Pidana Indonesia Ditinjau Dari Hukum Pidana Indonesia." e- Journal Komunitas Yustitia Universitas Pendidikan Ganesha Program Studi Ilmu Hukum. Vol. 3 No 1. (2020).

${ }^{16}$ Teuku Herizal, Dahlan Ali \& Mujibussalim, "Analisis Yuridis Pengembalian Aset Hasil Korupsi Melalui Gugatan Perdata Terhadap Ahli Waris.” Jurnal Ilmu Hukum Pascasarjana Universitas Syiah Kuala. Vol. 2 No. 3. (2014).
} 
Penjelasan narasumber M. Yusfidli Adhyaksana ${ }^{17}$ istilah pengembalian aset sepadan dengan istilah pemulihan aset yang berlaku di Kejaksaan Agung, menurut Banu Laksmana ${ }^{18}$ Selama ini Formulasi ketentuan pengembalian aset yang berlaku termuat dalam UU PTPK, Standar Internasional Peraturan pengambalian aset yang termuat dalam UNCAC 2003 serta UndangUndang No. 8 Tahun 2010 tentang Pencegahan dan Pemberantasan Tindak Pidana Pencucian Uang. Formulasi ketentuan pengembalian aset saat ini menurut menurut $M$. Adi Toegarisman $^{19}$ tertuang dalam standar internasional UNCAC 2003, UU PTPK, UU TPPU maupun tertuang dalam peraturan internal kejaksaan, sedangkan menurut Maroni ${ }^{20}$ formulasi ketentuan pengembalian aset hasil tindak pidana korupsi tertuang dalam Pasal 18 UU PTPK.

Perampasan aset hasil tindak pidana korupsi sangat tergantung kepada kemampuan penuntut umum dalam membuktikan kesalahan terdakwa di depan persidangan sekaligus membuktikan bahwa kejahatan tersebut terdapat hasil dari tindak pidana yang dia dakwakan. Konsep yang demikian ini dinamakan perampasan aset berdasarkan kesalahan terdakwa (Conviction Based Assets Forfeiture), yang terdapat dalam Pasal 39 dan Pasal 46 Ayat (2) KUHAP yang telah memberikan batasan tentang aset apa saja yang dapat disita. Pengembalian aset dari jalur tuntutan pidana ini dilakukan melalui proses persidangan di mana hakim di samping menjatuhkan pidana pokok juga dapat menjatuhkan pidana tambahan, dapat berupa: perampasan barang bergerak yang berwujud atau tidak berwujud atau barang yang tidak bergerak yang digunakan untuk atau yang diperoleh dari tindak pidana korupsi, termasuk perusahaan milik terpidana di mana tindak pidana korupsi dilakukan, begitu pula harta dan barang yang menggantikan barang-barang tersebut.Ketentuan tersebut diatur dalam Pasal 18 Ayat (1) huruf a UU PTPK.

Pengembalian aset tindak pidana korupsi melalui jalur keperdataan dapat dilakukan melalui aspek-aspek sebagai berikut: Gugatan perdata ditujukan kepada seseorang yang tersangkut perkara korupsi. (Pasal 32 ayat (1) UU PTPK), Gugatan perdata ditujukan kepada ahli waris dalam hal tersangka meninggal dunia pada saat dilakukan penyidikan, sedangkan secara nyata telah ada kerugian keuangan negara (Pasal 33, Pasal 38B ayat (2), (3) UU PTPK). Gugatan perdata terhadap terpidana dan atau ahli warisnya bila putusan telah berkekuatan hukum tetap (Ketentuan Pasal 34, Pasal 38B ayat (2), (3) UU PTPK).

Suatu strategi yang komprehensif dalam memerangi korupsi harus meliputi tindakantindakan yang ditujukan pada pencegahan dan penanggulangan pencucian uang hasil korupsi. Kehadiran Undang-Undang Nomor 8 Tahun 2010 tentang Tindak Pidana Pencucian Uang (UU TPPU) adalah sebagai upaya untuk membantu bekerjanya UU PTPK.

Pelacakan harta kekayaan tindak pidana pencucian uang dapat dilakukan pada tahap penyidikan oleh penyidik, tahap penuntutan oleh penuntut umum atau tahap persidangan oleh hakim, pelacakan tersebut dilakukan dengan meminta kepada pihak pelapor untuk memberikan keterangan secara tertulis mengenai harta kekayaan dari orang yang telah dilaporkan oleh PPATK kepada penyidik, tersangka atau terdakwa \{Pasal 72 ayat (1) UU TPPU\}. Penghentian transaksi keuangan dapat dilakukan oleh PPATK kepada penyedia jasa keuangan untuk menghentikan sementara seluruh atau sebagian transaksi yang diketahui atau dicurigai merupakan hasil tindak pidana (Pasal 65 ayat (1) UU TPPU), setelah 20 hari sejak penghentian transaksi tidak ada orang atau pihak ketiga yang mengajukan keberatan maka PPATK menyerahkan penanganan harta kekayaan tersebut kepada penyidik untuk dilakukan

\footnotetext{
${ }^{17}$ Hasil wawancara dengan M. Yusfidli Adhyaksana selaku Kabid Pemulihan Aset Transnasional pada Pusat Pemulihan Aset Kejaksaan Agung, Senin 08 April 2019.

${ }_{18}$ Hasil wawancara dengan Banu Laksmana, Kasubbid Pemulihan Aset Indonesia di Luar negeri pada Bidang Hansetrans, Senin 08 April 2019

${ }^{19}$ Hasil wawancara dengan M. Adi Toegarisman selaku Jaksa Agung Muda Tindak Pidana Khusus Kejaksaan Agung RI, Selasa 09 April 2019.

${ }^{20}$ Hasil wawancara dengan Maroni selaku Akademisi Fakultas Hukum Universitas Lampung. Jum'at 05 April 2019.
} 
penyidikan (Pasal 67 ayat (1) UU TPPU), setelah 30 hari penyidik tidak menemukan pelaku tindak pidana tersebut maka penyidik dapat mengajukan permohonan kepada pengadilan negeri untuk memutuskan harta kekayaan tersebut sebagai aset Negara atau dikembalikan kepada yang berhak (Pasal 67 ayat (2) UU TPPU). Ketentuan tersebut merupakan salah satu upaya perampasan aset tanpa pemidanaan atau non conviction based $(\mathrm{NCB})$ asset forfeiture. ${ }^{21}$ Aturan pelaksanaan perampasan aset tanpa pemidanaan tersebut tertuang dalam Peraturan MA (Perma) No.1 Tahun 2013 tentang Tata Cara Penyelesaian Permohonan Perampasan Harta Kekayaan dalam Tindak Pidana Pencucian Uang (TPPU) dan Tindak Pidana Lain.

Pemblokiran terdapat dalam salah satu Pasal Undang-Undang Pemberantasan Tindak Pidana Pencucian Uang Pasal 71 UU TPPU. Berdasarkan Pasal 77 UU TPPU Terdakwa harus membuktikan bahwa harta kekayaan yang dimilikinya bukan merupakan hasil dari tindak pidana atau dalam hal ini berlaku asas praduga bersalah (Presumption of Guilty) yaitu terdakwa dianggap telah menguasai harta kekayaan yang berasal dari kejahatan kecuali ia dapat membuktikan sebaliknya. ${ }^{22}$ Pembalikan beban pembuktian juga diatur di dalam Pasal 78 UU TPPU yang berbunyi: "Dalam pemeriksaan di sidang pengadilan hakim memerintahkan terdakwa agar membuktikan bahwa Harta Kekayaan yang terkait dengan perkara bukan berasal atau terkait dengan tindak pidana " Tujuan dari diberlakukan ketentuan ini adalah untuk merampas harta kekayaan yang berasal dari tindak pidana dan bukan untuk menghukum pelaku tindak pidana. ${ }^{23}$ Jika terdakwa tidak dapat membuktikan bahwa aset yang dimilikinya bukan berasal dari tindak pidana maka aset tersebut dirampas untuk negara,

\section{Formulasi Ketentuan Pengembalian Aset Hasil Tindak Pidana Korupsi di Masa Akan Datang}

Komitmen Negara Indonesia dalam menyempurnakan sistem hukum terkait dengan pencegahan, pemberantasan, dan pengembalian aset hasil tindak pidana korupsi, telah diwujudkan pada tanggal 18 April 2006 dengan meratifikasi UNCAC 2003 dengan UndangUndang Nomor 7 Tahun 2006 tentang Pengesahan United Nations Convention Against Corruption, 2003. Ratifikasi tersebut berisi pokok-pokok pikiran dalam rangka pencegahan, pemberantasan maupun pengembalian aset akibat tindak pidana korupsi. Salah satu ketentuan penting terkait konvensi tersebut adalah pengembalian aset seperti tercantum dalam Pasal 54 ayat (1) huruf c, Pasal ini mengamanatkan agar Negara-negara peserta mempertimbangkan untuk mengambil tindakan-tindakan yang dianggap perlu untuk membolehkan perampasan atas harta hasil korupsi tanpa penghukuman pidana atau NCB Asset forfeiture. Indonesia telah berupaya melaksanakan ketentuan Pasal 54 ayat (1) huruf c UNCAC 2003, dengan membuat Naskah Akademik Rancangan Undang-Undang (RUU) sejak Tahun 2012, sehingga melahirkan RUU tentang Perampasan Aset Tindak Pidana.

Formulasi ketentuan pengembalian aset pada masa yang akan datang menurut Banu Laksmana $^{24}$ diwujudkan melalui RUU perampasan aset tanpa pemidanaan/inrem, sedangkan menurut M. Yusfidli Adhyaksana ${ }^{25}$ dapat dikembangkan berdasarkan konsep Belanda, dengan istilah Criminal execution Investigation (CEI) / pemulihan aset pasca putusan pengadilan atau pemulihan aset pasca putusan berkekuatan hukum tetap, dimana dalam konsep tersebut berlaku setelah adanya putusan inkrah proses investigasi lanjutan meliputi pelacakan aset,

\footnotetext{
${ }^{21}$ Muhammad Yusuf, Merampas Aset Koruptor, Solusi Pemberantasan Korupsi di Indonesia, Jakarta, Kompas Media Nusantara, 2013, hlm. 167.

${ }^{23}$ Yunus Husein, Negeri Sang Pencuci Uang, Jakarta, PT. Pustaka Juanda Tigalima, 2008, hlm. 194.

${ }^{24}$ Hasil wawancara dengan Banu Laksmana, Kasubbid Pemulihan Aset Indonesia di Luar negeri pada Bidang Hansetrans pada Pusat Pemulihan Aset Kejaksaan Agung, Rabu 10 April 2019

${ }^{25}$ Hasil wawancara dengan M. Yusfidli Adhyaksana selaku Kabid Pemulihan Aset Transnasional pada Pusat Pemulihan Aset Kejaksaan Agung, Senin 08 April 2019.
} 
penyitaan dan perampasan dimungkinkan, CIE terbukti efektif meningkatkan kinerja Openbaar Ministerie (Kejaksaan Belanda) dalam melakukan pengembalian aset hasil tindak pidana di tataran internasional. Konsep yang lain untuk formulasi yang akan datang adalah perampasan aset terhadap keuntungan yang diperoleh dari hasil tindak pidana /profit of the posit/ winst van het positieve sebagai contoh terpidana membelanjakan uang hasil korupsinya untuk menanam saham di jaringan minimarket waralaba indomart maka keuntungan indomart dapat dirampas.

Menurut M. Adi Toegarisman ${ }^{26}$ Formulasi Ketentuan Pengembalian Aset Hasil Tindak Pidana Korupsi yang akan datang tidak terlepas dari pemikiran pemulihan kerugian keuangan Negara hal tersebut dapat diwujudkan dalam bentuk: memaralelkan/menyelaraskan unsur kerugian keuangan Negara dengan unsur yang ada dalam UNCAC 2003, dimana dalam UNCAC 2003 unsurnya bukan kerugian keuangan Negara, melainkan kerusakan aset Negara, sehingga cakupannya lebih luas dalam pengembalian aset; Pemberantasan tindak pidana korupsi saat ini hanya mengejar kerugian Negara, Formulasi kedepan dikembangkan kearah kerugian perekonomian rakyat; serta upaya memaksimalkan pengembalian kerugian keuangan Negara jangan dihitung pada saat korupsi itu dilakukan, formulasi yang akan datang seyogyanya memperhitungkan kerugian keuangan Negara dari sisi nilai/perkembangan nilai.

Menurut Irene Putrie ${ }^{27}$ formulasi pengembalian aset yang akan datang dengan mengesahkan RUU Perampasan aset, dimana RUU tersebut akan mengisi kekosongan hukum terhadap perkara yang tidak dapat disidangkan karena berbagai sebab yang sah antara lain terdakawa meninggal dunia, melarikan diri, sakit permanen atau perkara yang kurang alat bukti sehingga tidak bisa dituntut. Sedangkan formulasi ketentuan pengembalian aset yang akan datang menurut menurut Maroni2 ${ }^{28}$ diwujudkan dengan merevisi UU PTPK dan mengesahkan RUU Perampasan Aset Tindak Pidana.

Pengertian perampasan aset dalam RUU Perampasan Aset Tindak Pidana diatur dalam Pasal 1 ayat (3), berbunyi: Perampasan aset adalah upaya paksa yang dilakukan oleh Negara untuk merampas aset tindak pidana berdasarkan putusan pengadilan tanpa didasari pada suatu penghukuman terhadap pelakunya. Perampasan yang diatur dalam Pasal tersebut merupakan perampasan in-rem atau perampasan perdata, karena tindakan perampasan ditujukan bukan terhadap individu melainkan terhadap aset itu sendiri, perampasan perdata ini berbeda dengan gugatan perdata untuk kasus pidana sesuai yang diatur dalam Pasal 30 ayat 2 Undang-Undang Nomor 16 Tahun 2004 tentang Kejaksaan Republik Indonesia, menyebutkan kejaksaan dengan kuasa khusus dapat bertindak baik di dalam maupun di luar pengadilan untuk dan atas nama negara atau pemerintah di bidang perdata dan tata usaha negara sebagai Jaksa Pengacara Negara (JPN), peran jaksa pengacara negara dalam perkara pidana memperlakukan aset sebagai objek sengketa serta gugatan dialamatkan kepada pemilik aset/penguasa aset, berbeda dengan perampasan aset menurut RUU Perampasan Aset Tindak Pidana, dimana gugatan ditujukan terhadap aset itu sendiri, bukan pemilik aset/penguasa aset.

Pengembalian aset yang diatur dalam UU PTPK, UU TPPPU masih belum sempurna sehingga belum memaksimalkan pengembalian aset secara efektif dan efisien, Negara Indonesia perlu menerapkan standar Internasional yang termuat dalam UNCAC 2003, dimana dalam UNCAC tersebut terdapat mekanisme gugatan terhadap aset hasil kejahatan/in rem, jika dipadukan dengan in personam maka akan terbuka kesempatan yang luas untuk merampas aset hasil tindak pidana korupsi, dan aset lain sebagai sarana melakukan tindak

\footnotetext{
${ }^{26}$ Hasil wawancara dengan M. Adi Toegarisman selaku Jaksa Agung Muda Tindak Pidana Khusus Kejaksaan Agung RI, Selasa 09 April 2019.

${ }^{27}$ Hasil wawancara dengan Irene Putrie selaku Kepala Bagian Tata Usaha Pusat Pemulihan Aset Kejaksaan Agung RI, Senin 08 April 2019.

${ }^{28}$ Hasil wawancara dengan Maroni selaku Akademisi Fakultas Hukum Universitas Lampung. Jum'at 05 April 2019.
} 
pidana korupsi. Jika nantinya terdapat aset yang ditemukan dikemudian hari dan tidak tercantum dalam daftar aset yang telah disita atau dirampas berdasarkan putusan pengadilan berkekuatan hukum tetap, maka aset tersebut bisa dirampas melalui perampasan aset secara in rem, langkah ini sebagai solusi pemberantasan tindak pidana korupsi dan pencucian uang di Indonesia karena telah mengupayakan pengembalian aset hasil tindak pidana korupsi kepada negara selaku korban serta mencegah pelaku melakukan tindak pidana lain dengan menggunakan aset tersebut.

Pengembalian aset melalui jalur perdata yang terdapat dalam UU PTPK, berbeda dengan perampasan aset secara in rem, gugatan perdata yang terdapat dalam UU PTPK masih menggunakan hukum acara perdata biasa, dimana proses persidangan tunduk pada hukum perdata formil dan materil biasa, penuntut umum harus membuktikan adanya unsur kerugian negara.Berbeda dengan gugatan perdata inrem dimana pembuktian yang digunakan sudah menganut sistem pembuktian terbalik, dimana pihak-pihak yang merasa keberatan yang membuktikan bahwa aset yang digugat tidak ada hubungannya dengan perkara korupsi, serta inrem tidak berkaitan dengan pelaku tindak pidana dan memberlakukan aset sebagai pihak yang berperkara. Gugatan perdata dalam UU PTPK dapat dilakukan hanya setelah adanya status tersangka, terdakwa dan terpidana, sedangkan aset hasil tindak pidana korupsi mempunyai sifat berpindah tangan yang cepat, in rem dapat melakukan antisipasi perpindahan aset tersebut mengingat gugatan yang diajukan ke pengadilan bisa sebelum penetapan status tersangka atau bahkan sebelum mendapatkan pelaku tindak pidananya.

Perampasan aset menurut Undang-Undang Tindak Pidana Korupsi mengharuskan penuntut umum untuk membuktikan adanya kerugian keuangan Negara (Pasal 32, Pasal 33, Pasal 34 dan Pasal 38), berbeda dengan perampasan aset menurut Pasal 1 ayat 2 RUU Perampasan Aset Tindak Pidana, penuntut umum cukup membuktikan bahwa harta atau aset yang tidak wajar dipersamakan dengan aset atau harta yang bersumber dari tindak pidana.

Prosedur perampasan aset menurut Undang-Undang Tindak Pidana Korupsi dapat disarikan dari Pasal 5 sampai dengan Pasal 58, prosedur perampasan diawali dengan pemblokiran atau penyitaan oleh penyidik atau penuntut umum terhadap aset yang memenuhi kriteria aset yang dapat dirampas, kemudian penuntut umum mengajukan permohonan perampasan aset ke pengadilan negeri berdasarkan berkas pemblokiran atau penyitaan aset, setelah penuntut umum berpendapat berkas perkara telah memenuhi kelengkapan formil dan materiel dengan didukung alat bukti yang cukup. Kemudian majlis hakim yang ditunjuk ketua pengadilan negeri untuk menangani permohonan dari penuntut umum akan memanggil pihakpihak yang berkepentingan untuk dilakukan pemeriksaan, pembuktian dan mengeluarkan putusan perampasan aset.

Ketentuan dalam Pasal 2 dan Pasal 3 RUU Perampasan Aset Tindak Pidana, perampasan aset dapat diberlakukan kepada siapa saja yang memiliki aset yang diperoleh, diduga berasal dari tindak pidana, harta tidak seimbang dengan sumber penambahan hartanya dan tidak dapat membuktikan asal usul perolehannya secara sah. Harta yang tidak seimbang merupakan aset yang tidak wajar diperoleh dengan cara menghitung total harta dikurangi dengan penghasilan yang diperoleh secara sah. Sekilas ketantuan dalam RUU Perampasan Aset Tindak Pidana memberikan batasan yang luas bahwa harta yang berasal dari tindak pidana atau diduga diperoleh dari tindak pidana dapat dikenai tindakan perampasan, namun dalam Pasal 14 ayat (1) RUU Perampasan Aset Tindak Pidana memberikan batasan secara tegas aset yang dapat dirampas adalah aset hasil tindak pidana.

\section{Penutup}

Sebagai simpulan penelitian ini adalah formulasi ketentuan pengembalian aset hasil tindak pidana korupsi saat ini menganut konsep perampasan aset melalui putusan pengadilan 
yang telah memiliki kekuatan hukum tetap. Formulasi ketentuan pengembalian aset hasil tindak pidana korupsi pada masa yang akan datang diwujudkan dengan mempertimbangkan kepentingan Negara atau masyarakat selaku korban dari tindak pidana korupsi dengan menerapkan konsep Belanda yaitu pemulihan aset pasca putusan pengadilan, berdasarkan konsep perampasan aset terhadap keuntungan yang diperoleh dari hasil tindak pidana, serta menerapkan konsep perampasan aset secara perdata tanpa didahului sanksi pidana bagi pelaku tindak pidana korupsi sebagaimana telah dirumuskan dalam Pasal 1 ayat (3) RUU Perampasan Aset Tindak Pidana.

Saran dalam penelitian ini adalah hendaknya Pemerintah dan DPR melakukan harmonisasi ketentuan pengembalian aset yang terdapat dalam UU PTPK serta UU TPPU agar selaras dengan konsep pengembalian aset (Asset Recovery) yang diatur dalam UNCAC 2003 dan hendaknya pemerintah dan DPR menerapkan konsep pengembalian aset pasca putusan pengadilan dan konsep perampasan aset terhadap keuntungan yang diperoleh dari hasil tindak pidana terhadap perubahan UU PTPK, serta segera mengesahkan RUU Perampasan Aset Tindak Pidana menjadi Undang-Undang guna efektifitas pengembalian aset hasil tindak pidana korupsi.

\section{Daftar Pustaka}

A. Buku

Amrullah, M. Arief, 2004, Money Laundering Tindak Pidana Pencucian Uang, Bayumedia Publishing, Jawa Timur.

Atmasasmita, Romli, 2010, Globalisasi dan Kejahatan Bisnis, Prenada Media Group, Jakarta.

Effendy, Marwan, 2012, Kapita Selekta Hukum Pidana: Perkembangan dan Isu-Isu Aktual dalam Kejahatan Finansial dan Korupsi, Referensi, Jakarta.

Greenberg, Theodore S., 2009, Stolen Asset Recovery: A Good Practices Guide for Non-Conviction Based Asset Forfeiture, The international Bank for Reconstruction and Development The World Bank 1918 H Street NW Washington DC.

Hamzah, Andi,, 2007, Pemberantasan Korupsi: Melalui Hukum Pidana Nasional dan internasional, Edisi Revisi, PT. Raja Grafindo Persada, Jakarta.

Husein, Yunus, 2008, Negeri Sang Pencuci Uang, PT. Pustaka Juanda Tigalima, Jakarta.

Jahja, Juni Sjafrien, 2012, Melawan Money Laundering, mengenal, mencegah, \& memberantas tindak pidana Pencucian Uang, Visimedia, Jakarta.

Komisi Hukum Nasional RI, 2014, Kebijakan mendukung Pencegahan dan Pemberantasan Tindak Pidana Korupsi, Komisi Hukum Nasional RI, Jakarta.

Kristiana, Yudi, 2015, Pemberantasan Tindak Pidana Pencucian uang, perspektif hukum progresif, Thafa Media, Yogyakarta.

Makawimbang, Hernold Ferry, 2014, Kerugian Keuangan Negara dalam Tindak Pidana Korupsi, suatu Pendekatan Hukum Progresif, Thafa Media, Yogyakarta.

Mantovani, Reda dan R. Narendra Jatna, 2012, Rezim Anti Pencucian Uang dan Perolehan Hasil Kejahatan di Indonesia, CV. Malibu, Jakarta.

Mas, Marwan, 2014, Pemberantasan Tindak Pidana Korupsi, Ghalia Indonesia, Bogor.

Mulyadi, Lilik, 2015, Memahami dan Menghindari Perbuatan Merugikan Keuangan Negara dalam Tindak Pidana Korupsi dan Pencucian Uang, Thafa media, Yogyakarta.

Nasution, Bismar, 2009, Anti Pencucian Uang: Teori dan Praktek, Books Terrace \& Libray, Bandung.

Nawawi Arief, Barda, 1984, Teori-teori dan kebijakan pidana, Alumni, Bandung.

Pangaribuan, Luhut M.P., 2016, Hukum Pidana Khusus tentang Tindak Pidana Ekonomi, Pencucian Uang, Korupsi, dan Kerjasama Internasional serta Pengembalian Aset: Pengantar, Ketentuan dan Pertanyaan-pertanyaan, Kemang Studio Aksara, Jakarta.

Ramelan, Reda Mantovani dan Pauline David, 2008, Hukum Pidana, Komentar atas Pasal-Pasal Terpenting dari Kitab Undang-Undang Hukum Pidana Belanda dan Padanannya dalam Kitab Undang-Undang Hukum Pidana Indonesia, PT. Gramedia Pustaka Utama, Jakarta.

Requisitoire Law Enforcement \& Justice Magazine, Volume 31 Tahun 2013. 
Soewarsono, 2006, Penanganan Tindak Pidana Pencucian Uang (Money Laundering), Pusat Pengkajian Hukum, Jakarta.

Sumaryanto, Djoko, 2011, Pembalikan Beban Pembuktian: Tindak Pidana Korupsi dalam Rangka Pengembalian Kerugian Keuangan Negara, Prestasi Pustaka Raya, Jakarta.

Supanto, 2010, Kejahatan Ekonomi Global dan Kebijakan Hukum Pidana, Alumni, Bandung.

Tjokroamidjojo, Bintoro, 2000, Good Governance: Paradigma Baru Manajemen Pembangunan, UI Press, Jakarta.

Toegarisman, M. Adi, 2016, Pemberantasan Korupsi dalam Paradigma Efisiensi, Kompas Media Nusantara,Jakarta.

Topan, Mohammad, 2009, Kejahatan Korporasi di Bidang Lingkungan Hidup:Perspektif Viktimologi dalam Pembaharuan Hukum Pidana di Indonesia, Nusa Media, Bandung.

Tuanakotta, Theodorus M. , 2009, Menghitung Kerugian Keuangan Negara dalam Tindak Pidana Korupsi, Salemba Empat, Jakarta.

UNODC, 2009, Technical Guide To The United Nations Convention Against Corruption, United Nations New York.

Utama, Paku, 2013, Memahami Asset Recovery dan Gatekeeper, Indonesian Legal Roundtable, Jakarta.

Wiyono, R., 2008, Pembahasan Undang-Undang Pemberantasan Tindak Pidana Korupsi, Sinar Grafika, Jakarta.

Yanuar, Purwaning M., 2007, Pengembalian Aset Hasil Korupsi, Alumni, Bandung.

Yusuf, Muhammad, Dkk, 2011, Ikhtisar Ketentuan Pencegahan dan Pemberantasan Tindak Pidana Pencucian Uang, The Indonesia Netherlands National Legal Reform Program (NLRP), Jakarta.

-------, 2013, Merampas Aset Koruptor, Solusi Pemberantasan Korupsi di Indonesia, Kompas Media Nusantara, Jakarta.

B. Jurnal

Abdurofiq, A "Politik Hukum Ratifikasi Konvensi Pbb Anti Korupsi Di Indonesia." Jurnal Cita Hukum. Vol.4 No. 2, 2016: 189.

Ariawan, I. G. "Stolen Asset Recovery Initiative, Suatu Harapan Dalam Pengembalian Aset Negara." Jurnal Kertha Patrika. Vol. 33. No. 1, 2008.

Artha, I. K. "Vonis Sanksi Pidana Tambahan Oleh Hakim Berupa Pengembalian Kerugian Keuangan Negara Oleh Terpidana Tindak Pidana Korupsi Di Pengadilan Negeri Denpasar." Jurnal Magister Hukum Udayana. Vol. 6. No. 2, 2016: 295.

Ayu Puspita Sari Situmeang, D. G. "Pengembalian Aset Negara Yang Dicuri Sebagai Hasil Tindak Pidana Indonesia Ditinjau Dari Hukum Pidana Indonesi." Journal Komunitas Yustitia Universitas Pendidikan Ganesha Program Studi Ilmu Hukum. Vol. 3 No 1, 2020.

Deypend Tommy Sibuea, R. S. "Kebijakan Hukum Pidana Dalam Perampasan Aset Hasil Tindak Pidana Korupsi Di Indonesia." Diponegoro Law Journal Vol.5 No. 2, 2016: 2.

Habibi, M. "Independensi Kewenangan Komisi Pemberantasan Korupsi Pasca Perubahan Undang-Undang Nomor 30 Tahun 2002 tentang Komisi Pemberantasan Korupsi." Cepalo, 4 (1), 2020.

Hiariej, E. O. "Pengembalian Aset Kejahatan." Jurnal Opinio Juris. Vol. 13, 2013: 34.

Jerman, H. "Pemulihan Aset Hasil Kejahatan Sebagai Bentuk Perlindungan Hukum Terhadap Korban Kejahatan." DIH Jurnal Ilmu Hukum. Vol. 13 No. 25, 2017: 149.

Mahmud, A. "Problematika Asset Recovery Dalam Pengembalian Kerugian Negara Akibat Tindak Pidana Korupsi." journal Yudisial. Vol. 11. No. 3, 2018: 350.

Megawati. "Kebijakan Formulasi Sanksi Pidana Terhadap Pelaku Tindak Pidana Korupsi." USU Law Journal. Vol. 2. No. 3, 2014: 125.

Rakhmat, M. "Kewenangan Kejaksaan dalam Pengembalian Aset Hasil Korupsi melalui Instrumen Hukum Perdata." Mimbar: Jurnal Sosial dan Pembangunan. Vol. 31. No. 1, 2015: 203.

Sinulingga, E. E. "Pengembalian Aset Hasil Tindak Pidana Korupsi Melalui Mekanisme Gugatan Perdata." Jurnal Lex Administratum, Vol. V. No. 4, 2017: 124.

Tampubolon, S. M. "Peran Pemerintah Dalam Upaya Pemberantasan Korupsi Kaitannya Dengan UndangUndang No. 32 Tahun 2004." Jurnal Lex Et Societatis. Vol. II. No. 6, 2014.

Teuku Herizal, D. A. "Analisis Yuridis Pengembalian Aset Hasil Korupsi Melalui Gugatan Perdata Terhadap Ahli Waris." Jurnal Ilmu Hukum Pascasarjana Universitas Syiah Kuala. Vol. 2 No. 3, 2014.

Yulia, A. P. "Model Pengembalian Aset (Asset Recovery) Sebagai Alternatif Memulihkan Kerugian Negara Dalam Perkara Tindak Pidana Korupsi." Jurnal Hukum PRIORIS. Vol. 6 No. 1, 2017: 32. 